\title{
Analyze on the legal subjects of environmental protection with public trust doctrine
}

\author{
Linsha Li, Lingchun Meng \\ School of international education, Shanghai Jiao Tong University, Shanghai, China \\ Email address: \\ linsha@sjtu.edu.cn (Linsha Li), lcmeng@sjtu.edu.cn (Lingchun Meng)
}

To cite this article:

Linsha Li, Lingchun Meng. Analyze on the Legal Subjects of Environmental Protection with Public Trust Doctrine. International Journal of Environmental Monitoring and Analysis. Vol. 2, No. 3, 2014, pp. 145-150. doi: 10.11648/j.ijema.20140203.13

\begin{abstract}
The public trust doctrine is just like a precious stone, which originates from the English law and even the Roman law earlier. And it realizes the limitation on the administrative behavior and the ecological protection in the American environmental protection practice. It is used in more and more occasions, and turns to the jewel shining on the crown of environmental law. The doctrine clarifies that the administrative power is authorized by the public. The settlor is the public, and the government is entrusted. The public as the settlor and beneficiary possess the right to earnings of trust property. As the trustee, the government has the right of managing and disposing the property which bases on protecting the public benefit. Nowadays, the doctrine has turned into an important legal principle aiming at environmental protection. It includes not only the primary obligation to protect environment of the government, but the privilege of the citizen to ask the government for fulfilling its duty. The core of the theory lies in restricting the administrative power and maximizing the public benefit. Most damage caused by the environmental pollution can be avoided by the subjects taking their responsibility actively.
\end{abstract}

Keywords: Public Trust Doctrine, Environmental Protection, Settlor, Trustee, Beneficiary

\section{The Origin of Public Trust Doctrine}

The public trust doctrine can be traced formally to the Roman law. According to The Institutes of Justinian:

By the law of nature these things are common to mankind-the air, running water, the sea, and consequently the shores of the sea. No one, therefore, is forbidden to approach the sea-shore, provided that he respects habitations, monuments, and building, which are not, like the sea, subject only to the law of nations. ${ }^{[1]}$

So it emphasizes on the public use of natural resources originally. The English common law continues the doctrine and regulates that the nation possesses the sea, its subsoil and seashore. The nation undertakes the trust on public use of navigation, commerce and fishing. And the public trust is also suitable to the king's property. The nation has the privilege to transfer its property to the private, which should be limited by the public trust. So the public trust doctrine in Britain is to protect the public right of fishing and trading in the navigable water.

Later, the America inherits the public trust doctrine from the English common law. At the beginning, the doctrine also aims at protecting the traditional commercial benefit of fishing and navigation, excluding the entertainment, aesthetics or ecological environment. But since the environmental problems are increasing rapidly with the development of economy, the public trust doctrine is widely used gradually. Joseph Sax, the American professor delivered the public Trust Doctrine in Natural Resource Law: Effective Judicial Intervention in Michigan Law review in 1970, which introduces the public trust doctrine to the environmental protection domain and develops a new start. He regards the sunshine, water and wide fauna and flora as the public property of citizens, which are entrusted to the government. So it is the trust relationship which between the government and citizens.

Of all the concepts known to American law, only the public trust doctrine seems to have the breadth and substantive content which might make it useful as a tool of general application for citizens seeking to develop a comprehensive legal approach to resource management problems.

Sax also summarizes three types of restrictions by the public trust doctrine:

Three types of restrictions on governmental authority are often thought to be imposed by the public trust: first, the property subject to the trust must not only be used for a public purpose, but it must be held available for use by the 
general public; second, the property may not be sold, even for a fair cash equivalent; and third, the property must be maintained for particular types of uses. ${ }^{\text {[2] }}$

From then on, the core of the public trust doctrine turns to restrict the administrative power of natural resources and prevent the individual from environmental destruction. The doctrine plays an important role in the environmental protection practice. We will discuss it in detail in the next part.

According to the definition of Oxford Dictionary of Law, public trust refers to a trust for the benefit of the public. ${ }^{[3]}$ And Black's Law Dictionary describes the public trust doctrine as the principle that navigable waters are preserved for the public use, and that the state is responsible for protecting the public's right to use. ${ }^{[4]}$

The public trust stems from the trust frame. But the operation mode of trusteeship has changed from the unpaid tradition to the commercialized compensation with the development of social economy. And the trust property also changes from the real estate to financial assets. The trust companies acting as trustee are increasing rapidly, which promote the trusteeship to become a kind of trade among the equal parties. The trust companies manage the property for the beneficiary complying with the trust purpose and gain the reward. The relationship among the trust legal subjects reflects the concepts of the civil and commercial law such as freedom, equality, compensation of equal value which can be adjusted by the private law. But with regard to the public trust, the trustee is the government on behalf of public benefit, which is not the equal subject in the market and can't get any profit. So the public trust has the nature of public law beyond the area of private law.

The public trust doctrine is just like a precious stone, which originates from the English law and even the Roman law earlier. But the doctrine realizes the limitation on the administrative behavior and the ecological protection in the American environmental protection practice. It is used in more and more occasions, and turns to the jewel shining on the crown of American environmental law.

\section{The Development of the Public Trust Doctrine in the American Environmental Protection Practice}

\subsection{The Typical Cases Applying with the Public Trust Doctrine}

Arnold v. Mundy (1821) is the first case to affirm the public trust doctrine in America. The court of New Jersey reformulates the doctrine for the first time. To the plaintiff's claim to an oyster bed in the Raritan River adjacent to his farm, the court explains that the land on which water ebbs and flows, including the land between the high and low water, belongs not to the owners of the lands adjacent to the water, but to the state, to be held, protected, and regulated for the common use and benefit. ${ }^{[5]}$ Early understanding of the scope of public trust doctrine focuses on the preservation of natural water resources for navigation, commerce and fishing, and extending to the public rights in tidal lands for recreational uses, including bathing, swimming and other shore activities gradually.

Archaic judicial responses are not an answer to a modern social problem. Rather, we perceive the public trust doctrine not to be fixed or static, but one to be molded and extended to meet changing conditions and needs of the public it was created to benefit... ${ }^{[6]}$

In Illinois Central Railroad Company v. Illinois (1892), the Supreme Court regards the administrative assignment as invalid by applying the public trust doctrine. The Act of the Legislature of Illinois granted the submerged lands constituting the bed of Lake Michigan to the Illinois Central Railroad Company in 1869. But the land is so large and important that the company obstructed the Chicago harbor and impaired the public right in fact. So the Legislature repealed the act in 1873, which led to the dispute. The Supreme Court explains:

It is the settled law of this country that the ownership of and dominion and sovereignty over lands covered by tidewaters, within the limits of the several states, belong to the respective states within which they are found, with the consequent right to use or dispose of any portion thereof, when that can be done without substantial impairment of the interest of the public in the waters... The doctrine is founded upon the necessity of preserving to the public the use of navigable waters from private interruption and encroachment... There can be no irrepealable contract in a conveyance of property by a grantor in disregard of a public trust, under which he was bound to hold and manage it. ${ }^{[7]}$

Thereafter, the doctrine is widely used in the nationwide scope.

In National Audubon Society v. Superior Court (1983), the plaintiff files suit to enjoin the diversion of the department of water and power of the city of Los Angeles, which has taken virtually the entire flow of Mono Lake. Facing with the conflict between the scenic and ecological value of Mono Lake and the need for water of Los Angeles, the court concludes that:

The core of the public trust doctrine is the state's authority as sovereign to exercise a continuous supervision and control over the navigable waters of the state and the lands underlying those waters. ... before state courts and agencies approve water diversions they should consider the effect of such diversions upon interests protected by the public trust, and attempt, so far as feasible, to avoid or minimize any harm to those interests.

The parties acquiring rights in trust property generally hold those rights subject to the trust, and can assert no vested right to use those rights in a manner harmful to the trust.

The public trust is more than an affirmation of state power to use public property for public purposes. It is an affirmation of the duty of the state to protect the people's common heritage of streams, lakes, marshlands and tidelands, surrendering that right of protection only in rare 
cases when the abandonment of that right is consistent with the purposes of the trust. ${ }^{[8]}$

Once the state has approved an appropriation, the public trust imposes a duty of continuing supervision and the power to reconsider allocation decisions. The judgment attempts to integrate the values of both the public trust and the appropriative water rights, which is regarded as a milestone in the doctrine's development history.

\subsection{The Statute Law Including the Public Trust Doctrine}

The America explains and promotes the public trust doctrine in the specific cases, but the slow development and accumulation of the case law impedes the enlargement of the doctrine to some extent. The degree of application of the doctrine makes big difference among the states. And the doctrine isn't fully developed during one and a half century.

In the $60 \mathrm{~s}$ and $70 \mathrm{~s}$ of the 20 th century, the environmental destruction and pollution caused by the industrial development appeared rapidly, which attracted the public's attention on the environment and triggered the climax of protection movement. And the public doctrine is widely concerned due to its regulation and supervision on the administrative behavior. The scope of the doctrine extends from the normal legislation to the federal level, and even the constitutional law aiming at the environmental protection.

In Michigan Environmental Protection Act 1970, the air, water and other natural resources are enrolled in the protection scope of the public trust doctrine. And in the amendment in 1994, Natural Resources and Environmental Protection Act, its section 1701 is regulated as followed:

The attorney general or any person may maintain an action in the circuit court having jurisdiction where the alleged violation occurred or is likely to occur for declaratory and equitable relief against any person for the protection of the air, water, and other natural resources and the public trust in these resources from pollution, impairment, or destruction.

And the public trust is repeated more than 40 times thereafter, acquiring the government should take the public benefit into full consideration before issuing a permit of damming, dredging, or mining. Annual review is necessary and not less than $25 \%$ of the money credited to recreational projects shall be expended on projects to repair damages as a result of pollution, impairment, or destruction of air, water, or other natural resources. ${ }^{[9]}$

The Section 27 in Part 1 of the Constitution of the Commonwealth of Pennsylvania regards the state as the trustee of public natural resources. The people have a right to clean air, pure water, and to the preservation of the natural, scenic, historic and esthetic values of the environment. Pennsylvania's public natural resources are the common property of all the people, including generations yet to come. As trustee of these resources, the Commonwealth shall conserve and maintain them for the benefit of all the people. ${ }^{[10]}$

It is also stated in the first part of the National

\section{Environmental Policy Act of 1969:}

(The Nation should) fulfill the responsibilities of each generation as trustee of the environment for succeeding generations. ${ }^{[11]}$

A main idea of Sax in the environmental public trust is that the administrative power of the environmental property management should be supervised by means of citizen suit. Accordingly, the Clean Air Act regulates the provision of environmental citizen suit for the first time. It authorizes 'any person' can bring lawsuit against the government, administrator, and polluter in their own names. That is, 'any person' could commence an action against 'any person' alleged to be in violation of the law. ${ }^{[12]}$

Similar provisions are also regulated in the Clean Water Act, Toxic Substances Control Act, Resource Conservation and Recovery Act, Endangered Species Act and so on.

With more and more statute laws absorb the idea of public trust, the doctrine is widely acknowledged and fully developed. It becomes an accelerator to the environmental practice in America, which provides safeguard to the public to supervise the government as the trustee and encourages them to protect their own and public benefit actively.

Nowadays, the doctrine has turned into an important legal principle aiming at environmental protection. It includes not only the primary obligation to protect environment of the government, but the privilege of the citizen to ask the government for fulfilling its duty. The doctrine has also increasingly appeared in legal systems outside of the Britain and U.S., and becomes one of the effective tools of protecting the environment and natural resources.

\section{To Establish the Legal Relation between the Government and the Public with Public Trust}

The legal relation is the relationship between the interpersonal rights and obligations affirmed and adjusted by the norm of law. It consists of three elements: the subject of legal relation, the rights and obligations as the content and the object of rights and obligations.

In the legal relation of public trust, there are three parties of subject including settlor, trustee and beneficiary, and trust property as the object of rights. Comparing with the civil law and trust law, the former belongs to general law and latter special, and the regulation of public trust should be the special one in trust law. We will analyze the legal relation of the public trust between the government and the public in the environmental protection.

\subsection{The Rights and Obligations of the Settlor}

The settlor has the rights to obtain the information of trust property, adjust the management method, claim cancellation of the undue behavior of the trustee and even dismiss them. The settlor of trust includes the sane individuals, corporation or other organizations according 
with the law. And the settlor of public trust is the public representing the majority in the society. The public is a wide-scoped and dynamics concept. As the settlor of public trust, the public is the aggregation of the sane individuals, compared with the government as the trustee.

The trust relationship is generated due to the responsibility of government. The public as a whole, is the owner of common resources, but can't exercise the right to manage or dispose directly. The government is authorized to protect the public resources aiming at maximizing public benefit. This is not only the important duty but the reason of governmental being. As the settlor of the public trust, the public can adjust or repeal the undue management method of public resources, even ask for the punishment on the direct governor. But the most important right of the public should be the supervision on the basis of full information. Compared with the complex procedure of suit, the constant supervision on the management and disposal of the government is more effective to avoid damage. The right to be informed is important to the settlor, and also requires them to undertake the duty to supervise actively. If everyone is indifferent, the limitation on the administrative power can't be realized, thus the harmful result has to be undertaken by the public together.

\subsection{The Rights and Obligations of the Trustee}

The rights and obligations of the trustee, especially the obligations are the core of trust legal relation. The trust laws of many countries make detailed regulations such as for the maximum benefit of the settlor, being forbidden to seek personal gain, the responsibility of delegating, reporting, compensation and so on. As the trustee of public trust, the government should target for maximizing the public benefit, manage the public resources with honesty, credibility, caution and validity. The public authorize the administrative power to the government due to its justice, information and competence, and believe the self-discipline with high-level standard of its staff. But generally speaking, the obligations of the trustee regulated by trust law are conceptual, difficult to be measured and judged in the practice. As the administrative bureau of the nation, the government will exist in a relatively long-term period. In the public trust relation, the termination of the trustee will seldom occur. Therefore, the government should be loyal to the public and exercise the power appropriately. The governor should be responsible for the damage caused by undue behavior, and the enforceable remedy methods should be regulated in detail at the same time.

The right to be informed is the basis of supervision right of the settlor and the participation right of the beneficiary. In consideration of the hysteretic nature of environmental problems, professional data and difficulty of investigation, the public only can 'feel' or 'guess' the environmental situation instead of accurate information. The polluter will not be frank enough to admit the destruction caused by them, and pay the environmental bill initiatively. So, the information disclosure system of the government is the important guarantee to realize the public right to be informed. Accordingly, the foremost duty of the government as the trustee is to disclose the environmental information actively, timely and comprehensively.

\subsection{The Rights and Obligations of the Beneficiary}

The beneficiary is a special subject among the three parties of public trust, including the public as settlor, the administrative staff, and even the descendant. The serious problems caused by the environmental pollution let people realize that the natural resources will be exhausted by the unscientific use in the future. 'Don't let your tear becomes the last drop of water on the earth.' It is an advertising commentary for the public benefit, and touches many people deeply. The high cost of repair and irreversible destruction should be the Sword of Damocles on the top of everyone's head. With the crisis awareness, could our descendent enjoy the blue sky, green water, running water and the abundant gift of nature resources continuously.

The trust law generally authorizes the same rights to the beneficiary as the settlor. But compared with the settlor, the more important right of the beneficiary should be the participation right on the basis of the right to be informed. The participation in social affairs is also one of the public's obligations. Only every citizen takes the social responsibility actively, could the democracy of civil society be realized. Many countries have already formulated the law or regulation of public participation, which including the methods of investigation, consultant, forum, discussing meeting and hearing. But the key point is how to avoid becoming a nominal process and get the opinions of the influenced public effectively. Since the right and obligation supplement each other, it is necessary for the public to establish the mature civil consciousness. The basis of protecting one's own right lies in the social responsibility and obligation he undertakes.

\subsection{The Public Benefit as Trust Property}

The purpose of public trust is to promote the government to utilize the public resources rationally, maintain and increase the social benefit. The public benefit is a word of high abstraction, which appears frequently in our daily life but is difficult to define accurately. It is necessary to clarify the scope of the public benefit, so that the purpose of the public trust can be realized.

Black's Law Dictionary defines public interest as the general welfare of the public that warrants recognition and protection. [13] The prominent difference between the environmental law and the others is that the object protected is the common interest of the public or not. So the environmental protection asks for more responsibility of supervision and governing of the government, besides the citizen participation. The public benefit is on the basis of the private person's, but can't sum them simply or be partial to the minority. It should be acknowledged by the majority, withstand the objective measurement, be 
protected by the law and coordinate with the value of social development.

It pasts more than 400 years since the Britain issued the first charities act in 1601. The Britain amends the law according to the changing social economy for dozens of times, and the definition of scope and organization is relatively mature, which can be used for reference. Charities Act 2011 regulates one of the commission's objectives should be the public benefit, which is to promote awareness and understanding of the operation of the public benefit requirement. The act also requires the commission to issue guidance in pursuance of its public benefit objective, and the charity trustees must have regard to any such guidance when exercising any powers or duties to which the guidance is relevant.

Accordingly, the commission issued public benefit guides in 2013. It states that in general, for a purpose to be 'for the public benefit' it must satisfy both 'benefit' and 'public' aspects. For the 'benefit' aspect, a purpose must be beneficial and any detriment or harm that results from the purpose must not outweigh the benefit. And for the 'public', it should benefit the public in general, or a sufficient section of the public and not give rise to more than incidental personal benefit. ${ }^{[14]}$ The guidance also emphasizes the different definition of public benefit in various conditions, and integrates some cases to explain the requirement in detail.

Due to the particularity of environment, the scope of public benefit in the environmental protection is more extensive. The influence will not be limited to current time and location, but extend to the living quality of the descendant and trans-regional persons. The concept of public benefit is so flexible that its scope will vary with different time and location. But all in all, it should be defined by the influenced public or their delegates together there and then, and be safeguarded by the governmental enforcement.

The public trust and charitable trust are both the special regulations in trust law, aiming at increasing the public welfare. But they are different in the aspects of parties, establishment, objects and supervisors. Comparatively, the system of charitable trust is built earlier, and widely used in the countries with trust law system. So it can be used for the public trust's reference by clarifying the similarity and diversity. The differences between them are as followed:

\begin{tabular}{lll}
\hline & Public trust & Charitable trust \\
\hline Settlor & the public as a whole & private persons or organizations \\
Trustee & the administrative bureau & sane persons or corporations, approved by the public welfare agency \\
Beneficiary & contemporaries and descendent & unqualified majority \\
Objects & the right of public resources management & property right in general, such as charitable trust capital \\
Establishment & administrative power & the settlor transfers the trust property to the trustee \\
supervisors & superior, legislation, justice department, and the public & trust superviser
\end{tabular}

\section{The Significance of Public Trust Doctrine to the Environmental Protection}

\subsection{Constructing the Trust System Reasonably}

Confidence is the first element of the trust, which is regarded as the dependency relationship in the social science. Without confidence, it's hard to imagine that the settlor would transfer his property to the others, abandon the right of management, and even face with the risk of no legal protection.

As the administrative bureau, the government comes into being on the basis of public confidence. The legality of government derives from contract. As Brennan and Buchannan states in The Reason of Rules, the people establish the government to protect the rights recognized by the contract. The government or its agent who modifies or changes the people's right arbitrarily certainly will breach the spirit of contract. ${ }^{[15]}$ In the theory of public trust doctrine, the public authorize the right of managing public resources to the government on the basis of confidence. They want to acquire the individual's interest when the public benefit is maximized. As Jefferson says, the person who gains the confidence of the public should regard himself as the public property. But the venal and selfish behavior of some staffs in the government will erode the credibility and cause the crisis of confidence. The primary requirement proposed by the public trust doctrine is to establish the confidence system reasonably. With the increasing environmental awareness of the public, the fresh air, clean water and favorable environment are the important indicators to measure the level of government's public service. 'Vote by foot' is the direct evaluation of the local government by the public.

The service spirit of government is improving in recent years. The measures such as information disclosure, public participation and transparent administration aiming at enhancing the governmental confidence are implemented in practice. But the systematic operation still calls for 'strict scrutiny' of the judicial organ on one hand, and the public supervision on the other hand. The combination will establish the trust network of governance effectively. Only the government obtains credibility, will let the public believe that it would make good use of and protect public resources.

\subsection{Increasing the Public Benefit Effectively}

According to the public trust doctrine, the public own the right of public resources as the settlor, and the government is authorized the right of managing to maximize public benefit. Due to the nature of non-competitiveness and non-excludability of public goods, the resource allocation usually falls into the inefficient or invalid status which is called 'the tragedy of the commons'. And there is a long 
period of incubation after the damage of environmental resources happens.

As the special object of right, the environmental resources can' be monopolized by the individual, so it's necessary for the government to provide the legal and political protection for equal right. Many resources will not regenerate once exhausted, so it's necessary for the government to formulate the long-term program and make scientific use planning as a whole. There is negative externality of the environmental pollution which will cause the minority obtain the benefit instead of the majority, so it's necessary for the government to supervise strictly and penalize the unlawful act. The cost of environmental protection and repair is so high that it is necessary for the government to bear the charges with the public fund to benefit the public and their descendent continuously. Most part of the pollution result and cost payment can be avoided to some extend if these methods are applied at the beginning.

The uncertainty of the concept of public benefit needs the scientific estimation of the administrative bureau representing the public. In the case of Tennessee Valley Auth. v. Hill in 1978, the U.S. Supreme Court states, the completion of the Tellico Dam will lead to the extinction of the snail darter, which belongs to the endangered species in the Little Tennessee River. Because 'the endangered species are to be accorded the highest priorities', the virtually completed dam expended more than $\$ 100$ million was sentenced to halt. ${ }^{[16]}$ The economical interest is obvious, while the ecological benefit is incalculable. The court thinks that it is difficult for them to balance the loss of a sum certain against an incalculable value, and the latter need to be protected whatever the cost. More than 90 percent of the U. S. citizens investigated accept it - the power plant can be built elsewhere, but the snail darter will not regenerate once extinct.

\subsection{Establishing the Service-Oriented Government}

The public trust doctrine clarifies that the administrative power is authorized by the public. The settlor is the public not the superior, and the government is entrusted. The public as the settlor and beneficiary possess the right to earnings of trust property. As the trustee, the government has the right of managing and disposing the property which bases on protecting the public benefit. Any individual of the government can't handle the public resources according to his own preference.

The public's specific right of the public goods surpasses the private right including the right of the government. It is the government's obligation to administer by law and be supervised by the public. From the hierarchy bureaucrat of Weber to the new public management focusing on the reform with enterprise spirit, and the current govern method of democratic consultation, the public are not the ones who obey the administrative orders simply or the clients who accept the contract service any longer. They should be the steersman of the direction of national development through active participation in the political system. The necessity of the existence of modern government is to response to the problems and affairs issued by the public, and promoting the common interest by means of perfecting public service. During the process of policy regulation, the government should provide the guidance and support to the public, and therefore increase its legality. Thus democracy and rule of law can be realized. One basic principle of modern rule of law is that the public power only can be exercised when the law allows, and the citizen can enjoy the power whenever the law doesn't forbid. With the development of the social economy and system perfection, the emphasis of the law should turn to protect the citizen's right. And the core of the public trust doctrine lies in restricting the public power and safeguarding the public benefit exactly.

\section{References}

[1] The Institutes of Justinian, LIB. II . TIT. I .1

[2] Joseph L. Sax, The public Trust Doctrine in Natural Resource Law: Effective Judicial Intervention, Michigan Law review, pp.474. pp.477

[3] Oxford Dictionary of Law, Oxford University Press, fifth edition, 2003, pp.397.

[4] Black's Law Dictionary, 8th ed. 2004, pp.3889.

[5] Arnold v. Mundy, 6 N.J.L. 1, 53 (1821)

[6] Raleigh Avenue Beach Association v. Atlantic Beach Club, Inc., et al.325 (2005)

[7] Illinois Central Railroad Company v. Illinois, 146 U. S. 435 . 436、389(1896)

[8] National Audubon Society v. Superior Court, 33 Cal. 3d 425 、 426、437、441 (1983)

[9] Natural Resources and Environmental Protection Act, Act 451 of $1994,324.1701,324.31514,324.32515,324.63207$, 324.71108

[10] Constitution of the Commonwealth of Pennsylvania, Section 27

[11] The National Environmental Policy Act of 1969, Sec101 (b)1

[12] Clean Air Act, 7604(a)

[13] Black's Law Dictionary, 8th ed. 2004, pp.3883.

[14] http://www.charitycommission.gov.uk/detailed-guidance/cha ritable-purposes-and-public-benefit/public-benefit-the-publi c-benefit-requirement-pb1/part-2-what-for-the-public-benefi t-means/

[15] Geoffrey Brennan, James M. Buchanan, The reason of Rules: Constitutional Political Economy, Cambridge University Press, 1985, pp.31

[16] Tennessee Valley Auth. v. Hill, 437 U.S. 155 (1978) 